\title{
Effect of Chemical Fertilizers on Water Quality of Irrigation Reservoir (Kaliasote Reservoir) of Bhopal (M.P.)
}

\author{
GANESH RAM NAMDEV, AVINASH BAJPAI ${ }^{1}$ and SUMAN MALIK² \\ Department of Chemistry Sadhu Vaswani College Bhopal (India). \\ ${ }^{1}$ Makhanlal University Bhopal (India). \\ ${ }^{2}$ Head of Department of Chemistry, Sadhu Vaswani College, Bhopal (India).
}

(Received: March 25, 2011; Accepted: April 30, 2011)

\begin{abstract}
The use of chemical fertilizers in the catchment area of the Kaliashote reservoir has increased many fold thus, residual impact of the chemical fertilizer as well as agriculture waste inflow in the lake considerably increased water pollution problem. The residues of the chemical fertilizer reaching to the Kaliashote reservoir with storm water enriched the lake water with the loading of nutrients. The extra loading of the nutrient causes eutrophication that supports luxuriant growth of macrophytes. Results of analyzed of several physicochemical parameters such as $\mathrm{pH}$, Conductivity, Dissolved Oxygen(DO), Biological Oxygen demand(BOD), Chemical Oxygen demand(COD), Nitrates ,Phosphates and Potassium shows high concentration of nutrients in the areas where chemical fertilizer are being used (at the station near Bhadbhada) in comparison Reference sample i.e. Behind MACT, Kaliasote Reservoir.
\end{abstract}

Key words: Eutrophication, Chemical Fertilizers, Organic Fertilizers, Water Quality

\section{INTRODUCTION}

The Kaliasote reservoir is situated near the Water and Land Management Institute(WALMI) Bhopal, and was constructed as a storage dam to conserve excess water of Upper Lake, discharged through the Bhadbhada spill gates of the lake for irrigation purposes. The reservoir is having a catchment of $381.38 \mathrm{Km}^{2}$ and the gross capacity is 35.387 Mecum . The reservoir is also facing the problem of siltation due to rapid change in land use pattern from agriculture to housing. The catchment area is surrounded by agriculture land where fertilizers and pesticides are being used. Under present investigation two sampling stations were identified one at Near Bhadbhada where Chemical Fertilizers are being used and the other one at Reference sample i.e. Behind MACT .

\section{MATERIAL AND METHODS}

Water samples were collected in fresh 2.5 L plastic containers previously washed with $1: 3$ $\mathrm{HNO}_{3}$ during the post monsoon months i.e. September-2010 from surface and bottom water .

$\mathrm{pH}$ was determined using digital $\mathrm{pH}$ meter. Conductivity was measured using digital conductivity meter. Dissolved Oxygen was determined by the Wrinkler's method with Azide modification. Biological Oxygen Demand was determined by five days method. Chemical Oxygen Demand determined by Potassium Dichromate Pen Reflux method. Nitrate \& phosphate were estimated by UV-visible Spectrophotometer. Potassium was determined by using Flame Photometer . 


\section{RESULTS AND DISCUSSION}

Water quality standards and guidelines corresponding to the ISI ,WHO, CPCB have been compared with the results under the given tables and graphs .

\section{$\mathrm{pH}$ and Conductivity}

$\mathrm{pH}$ is largely depend on carbonates bicarbonates, $\mathrm{CO}_{2}$. The results of $\mathrm{pH}$ ranged in between 7.1-7.6 indicating that the lake water is slightly alkaline. Desirable $\mathrm{pH}$ range is $7.0-8.5$ as per WHO , ISI . Conductivity is depended on $\mathrm{SO}_{4}, \mathrm{Cl}, \mathrm{PO}_{4}$ and heavy metals and total concentration of dissolved ions. The results of analysis in between 269-768 micro-ohms/cm . The conductivity standard value is $50-1500$ micro-ohms/ $\mathrm{cm}$.

\section{Dissolved Oxygen(DO)}

DO in water is of great importance to all aquatic organism and is considered to be the factor that reflects the biological activity taking place in a water body and influences the biological changes . In the present study DO values were found in between $3.2-8.8 \mathrm{mg} / \mathrm{L}$ against the standard value of $6.0 \mathrm{mg} / \mathrm{L}$.

\section{Biological Oxygen demand(BOD)}

$B O D$ is directly linked with decomposition of dead organic matter present in the lake and hence the higher values of BOD can be directly co-related with pollution status and has an inverse relation with DO concentration. The BOD values were observed in between 1.2-7.2 mg/L . The permissible limit is 3-6 mg/L .

\section{Chemical Oxygen demand(COD)}

The range of COD was observed in between $30-52 \mathrm{mg} / \mathrm{L}$ while the permissible limit is $10.0 \mathrm{mg} / \mathrm{L}$.

\section{Nitrate $\left(\mathrm{NO}_{3}\right)$, phosphate $\left(\mathrm{PO}_{4}\right)$ and Potassium}

Nitrate and phosphate are two important nutrients in the lake for eutrophication process . These nutrients support the fast growth of aquatic plant . In the present study, the results of nitrate in between 1.16-2.69 mg/L . and results of phosphate was in between $1.33-2.56 \mathrm{mg} / \mathrm{L}$. This range were observed exceeds the permissible limit because

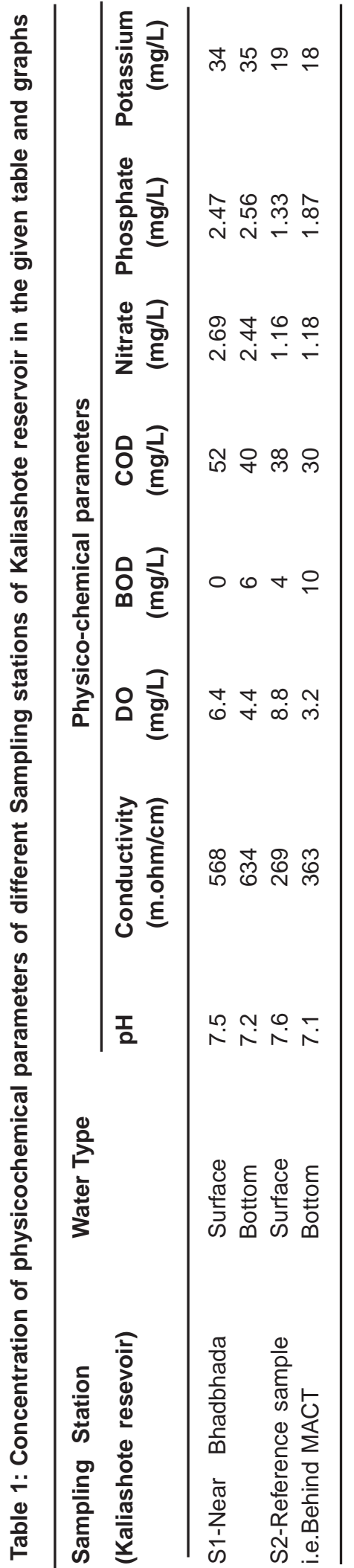




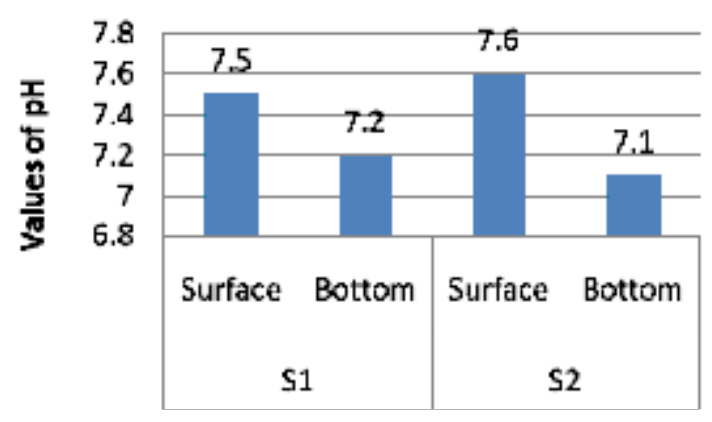

Fig. 1: Variation in $\mathrm{pH}$ in different stations of Kaliashote resevoir

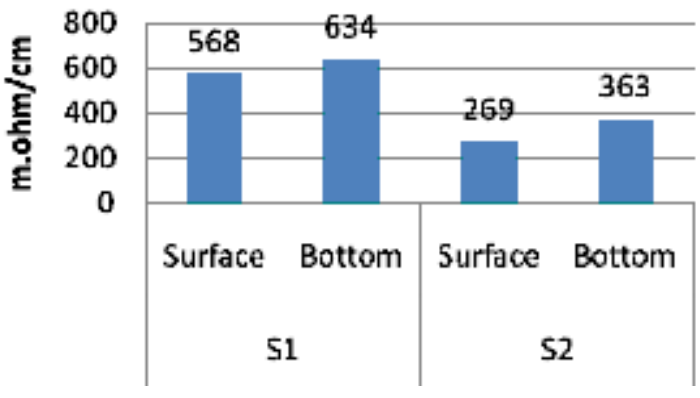

Fig. 2: Variation in conductivity in different stations of Kaliashote resevoir

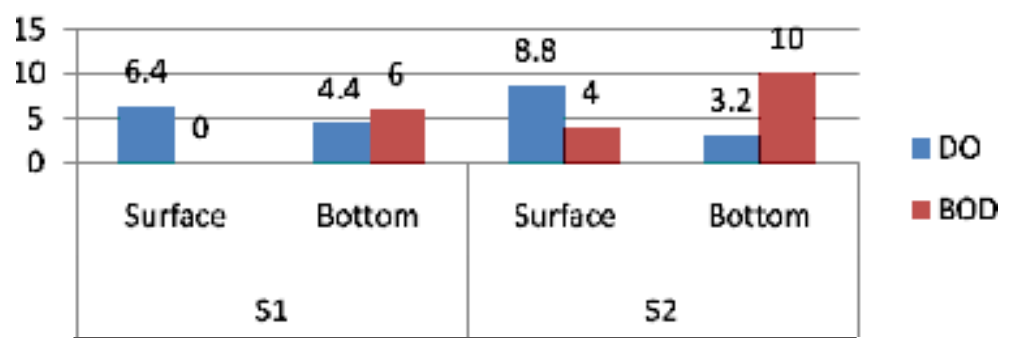

Fig. 3: Variation in DO and BOD in different stations of Kaliashote resevoir

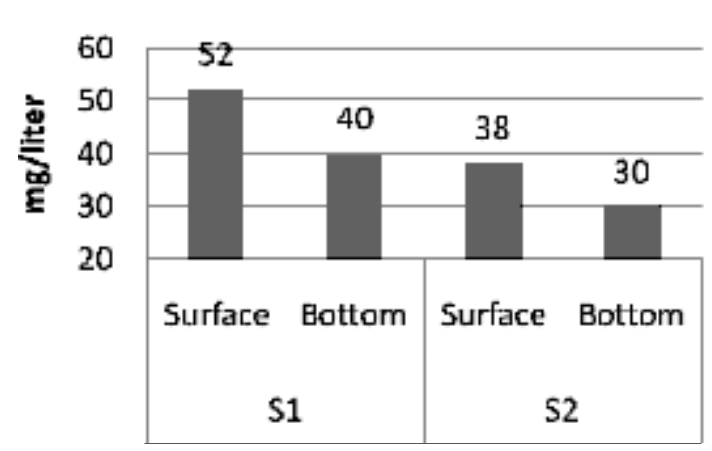

Fig. 4: Variation in COD in different stations of Kaliashote resevoir

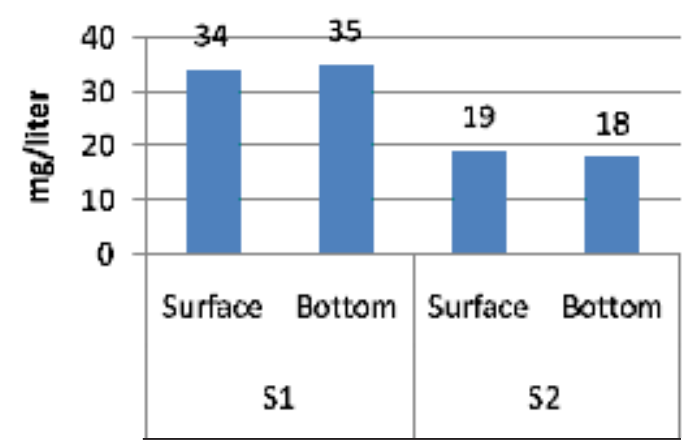

Fig. 6: Variation in Potassium in different stations of Kaliashote resevoir

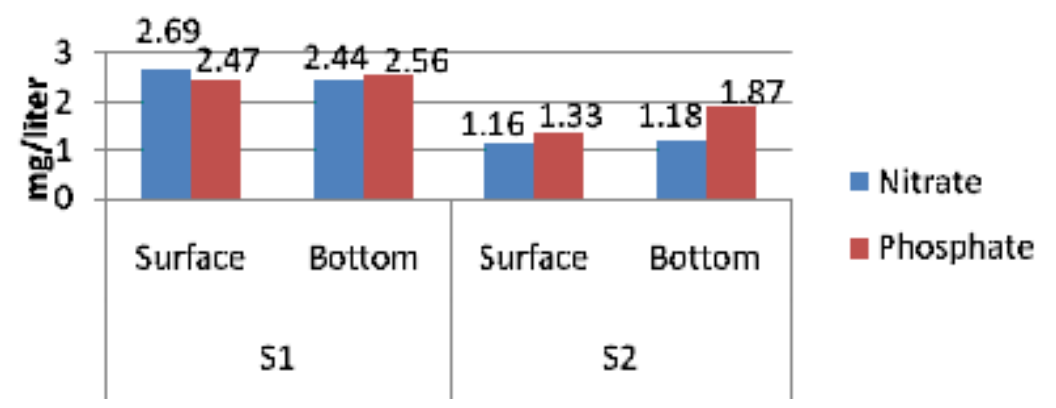

Fig. 5: Variation in Nitrate and Phosphate in different stations of Kaliashote resevoir 
excessive use of chemical Fertilizers . Potassium ranged in between $18.0-35.0 \mathrm{mg} / \mathrm{L}$. The values were observed beyond the permissible limit .

\section{CONCLUSION}

The comparative analysis depicts that, higher concentration of nutrients both nitrates as well as phosphates in the water samples of near Bhadbhada which is being predominantly cultivated with chemical fertilizers especially with Urea, DAP, Super Phosphate etc. The availability of the higher concentration of nutrients in water due to intensive use of chemical fertilizer in the catchment area of the reservoir would accelerate the process of eutrophication. The water samples collected from Reference sample i.e. behind MACT, Kaliasote reservoir has comparatively lower concentration of nutrients. Thus, the present study recommends the use of organic fertilizer in place of chemical fertilizer which would not only improve the soil fertility but also help in reducing the enrichment of nutrients the reservoir water because of chemical fertilizer .

\section{ACKNOWLEDGEMENTS}

The authors are thankful to Principal, Sadhu Vaswani college Bhopal for providing me Laboratory Facilities and encouragement.

\section{REFERENCES}

1. Alexander K.C., Limnological studies of Upper lake and Lower lake of Bhopal. Ph.D. Thesis, Vikram University, Ujjain (1976).

2. Singh Mudhulika, Borana K., Bajpai Arun, Bajpai Avinash, Pani S., Monthly variation on insects of lower lake, Bhopal in relation to macrophytes" PP in national workshop on new economic policy,( 1997), 15th \& 16th December Bhopal (1997).

3. Raddy, M.S. and shastry, V.V.K., Effect of irrigation level of phosphorus and potassium movement in red loam soil of Andhra Pradesh. Jou. of Indian society of soil science, 31: 8-12 (1983).

4. $\quad \mathrm{APHA}($ American Public Health Association): American Water Works Association and Water Pollution Control Federation, Standard Methods for the Examination of Water and Wastewater, $19^{\text {th }}$ ed., American Public Health Association, Washington (1995).

5. APHA(American Public Health Association): American Water Works Association and Water Pollution Control Federation, Standard Methods for the Examination of Water and Wastewater , 20 th $e d$. ., American Public Health Association, Washington (2005).

6. Azad B.S., Gupta S.C. \& Peer A.C., Influence of organic and inorganic fertilizer in maximizing wheat yield at irrigated condition. environment and ecology, 16: 71-73 (1998).

7. Bajpai Avinash, Bajpai Jyoti \& Praveen Tamot. Catchment area activities and land use pattern of upper lake, Bhopal, PP in national workshop on new economic policy. 1997, 15th \& 16th December Bhopal (1997).

8. Bajpai A., Misra S.M., Tamot S., Agrawal A., Limnological studies to assess water quality of Upper Lake, Bhopal . In: Proceedings, Nat. Sem. On Conserv. And Dev. of Aqua. Resour. 23-24 Dec. pp 20 (1993).

9. Jain, R.K., Studies the effect of excessive use of fertilizers on the quality of ground water in Barna command area district Raisen. Ph.D. thesis no. 3937, Barkatullah University, Bhopal (1993).

10. Misra S.M., Pani and Bajpai A., Solid waste - A social problem and responsibility of the community., PP in National Seminar on Policy Planning's \& Techno-regulatory Input for Solid Waste Management 27th-28th March 2001, Bhopal (2001).

11. Parashar Charu, Verma Neelam., Dixit Savita., Shrivastava Rajnish, Multivariate analysis of drinking water quality parameters in Bhopal. Environ. Monit. Assesss. (DOI 10.1007/s10661-007-9853-5) (2007).

12. Pawar, C.T. and Joshi, M.V., Impact of urbanization and industrialization on water quality. nat., env. pall. tech. 1(4): 351 (2002).

13. Jumbe Aboud S. and Nandini N., Physicochemical and Heavy Metals Evaluation of Polluted Urban Wetlands of Bangalore .RJCE 14(2): (22-35) (2010). 